\title{
PENGARUH KOMPENSASI TERHADAP KEPUASAN KERJA KARYAWAN PADA BAGIAN PRODUKSI DI PT. ETOWA PACKAGING INDONESIA
}

\author{
Septerina ${ }^{1}$, Rusda $\operatorname{Irawati}^{2}$ ) \\ 1) Prodi Administrasi Bisnis Terapan Politeknik Negeri Batam, email: septe87@gmail.com \\ 2) Prodi Administrasi Bisnis Terapan Politeknik Negeri Batam, email: ira@ polibatam.ac.id \\ abstract
}

\begin{abstract}
Proper employee compensation will keep them motivated to improve their performance in a vigorous manner so that the results achieved from the job can give their employees satisfaction. This study aims to determine the effect of financial compensation on employee job satisfaction on the production in PT. Etowa Packaging Indonesia, to determine the effect of non-financial compensation on employee job satisfaction on the production at PT. Etowa Packaging Indonesia, and to know the influence of financial compensation and non-financial compensation simultaneously to job satisfaction of production employee at PT. Etowa Packaging Indonesia. The research design conducted by researchers is explanatory research. With a population of 253 respondents taken a sample of 171 respondents. The instrument of data collection used is observation and spreading of questionnaire. Data were analyzed using descriptive statistics and multiple regression analysis. The results stated that financial compensation and non financial compensation after tested partially or together significantly influence the employee job satisfaction in the production at PT. Etowa Packaging Indonesia.
\end{abstract}

Keywords: Compensation Financial, Non Financial Compensation, Employee Satisfaction

\section{abstrak}

Pemberian kompensasi kepada karyawan secara tepat akan membuat mereka termotivasi untuk meningkatkan kinerjanya dengan giat sehingga hasil yang dicapai dari pekerjaan tersebut dapat memberikan kepuasan tersendiri bagi karyawan tersebut. Penelitian ini bertujuan ntuk mengetahui pengaruh kompensasi finansial terhadap kepuasan kerja karyawan pada bagian produksi di PT. Etowa Packaging Indonesia, untuk mengetahui pengaruh kompensasi non finansial terhadap kepuasan kerja karyawan pada bagian produksi di PT. Etowa Packaging Indonesia, dan untuk mengetahui pengaruh kompensasi finansial dan kompensasi non finansial secara simultan terhadap kepuasan kerja karyawan bagian produksi di PT. Etowa Packaging Indonesia. Rancangan penelitian yang dilakukan oleh peneliti adalah explanatory research. Dari populasi sebanyak 253 responden diambil sampel sebanyak 171 responden. Instrumen pengumpulan data yang digunakan adalah observasi dan penyebaran kuesioner. Data dianalisis menggunakan statistik deskriptif dan analisis regresi berganda. Hasil penelitian menyatakan bahwa kompensasi finansial dan kompensasi non finansial setelah diuji secara parsial maupun bersama-sama berpengaruh secara signifikan terhadap kepuasan kerja karyawan di bagian produksi pada PT. Etowa Packaging Indonesia.

Kata Kunci: Kompensasi Finansial, Kompensasi Non Finansial, Kepuasan Kerja Karyawan 


\section{PENDAHULUAN}

Sumberdaya manusia merupakan salah satu faktor terpenting dalam suatu perusahaan. Peran serta sumberdaya manusia yang terampil, kreatif dan inovatif akan membantu perusahaan untuk mencapai tujuannya. Persaingan dalam era globalisasi sekarang ini menuntut perusahaan untuk menyediakan sumberdaya manusia yang berkualitas akan mendukung kinerja perusahaan. Untuk terus meningkatkan kualitas kerja karyawan perusahaan harus memberikan umpan balik berupa kompensasi sesuai dengan peraturan perundangundangan ketenagakerjaan yang berlaku di masing-masing negara.

Pemberian kompensasi kepada karyawan secara tepat akan membuat mereka termotivasi untuk meningkatkan kinerjanya dengan giat sehingga hasil yang dicapai dari pekerjaan tersebut dapat memberikan kepuasan tersendiri bagi karyawan tersebut. Agar kepuasan kerja tersebut dapat tercapai perusahaan hendaknya memperhatikan apa yang menjadi kewajiban perusahaan. Perusahaan wajib memberikan imbalan kepada karyawannya secara merata dan adil sesuai dengan pekerjaannya.

Menurut Wahjono (2008) kompensasi adalah segala sesuatu yang diterima oleh karyawan sebagai imbalan atas sumbangannya kepada perusahaan, termasuk di dalamnya adalah gaji, pemberian tunjangan, fasilitas-fasilitas yang dapat dinikmati karyawan baik yang berupa uang maupun yang non keuangan.

Menurut Yani (2012) jenis-jenis kompensasi dapat dibedakan menjadi dua bentuk, yaitu:

\section{Kompensasi dalam bentuk finansial}

Kompensasi finansial dibagi menjadi dua bagian, yaitu kompensasi finansial yang dibayarkan secara langsung seperti gaji, upah, komisi dan bonus. Kompensasi finansial yang diberikan secara tidak langsung seperti tunjangan kesehatan, tunjangan pensiun, tunjangan hari raya, tunjangan perumahan, tunjangan pendidikan dan lain sebagainya.

\section{Kompensasi dalam bentuk non finansial}

Kompensasi non finansial dibagi menjadi dua macam, yaitu yang berhubungan dengan pekerjaan dan yang berhubungan dengan lingkungan kerja. Yang berhubungan dengan pekerjaan, misalnya kebijakan perusahaan yang sehat, pekerjaan yang sesuai (menarik, menantang), peluang untuk dipromosikan, mendapatkan jabatan sebagai simbol status. Sedangkan kompensasi non finansial yang berhubungan dengan lingkungan kerja seperti ditempatkan di lingkungan kerja yang kondusif, fasilitas kerja yang baik dan lain sebagainya.

Kompensasi finansial yang dianggap sesuai dengan apa yang mereka kerjakan serta kompensasi non finansial yang mereka anggap sesuai dengan apa yang telah mereka berikan akan menimbulkan perasaan senang. Karyawan yang senang dalam menjalankan pekerjaannya secara tidak langsung akan memberikan kepuasan kerja terhadap apa yang mereka kerjakan.

Menurut Wahjono (2008) kepuasan kerja adalah hasil persepsi para karyawan tentang seberapa baik pekerjaan seseorang memberikan segala sesuatu yang dipandang sebagai suatu yang penting melalui hasil kerjanya. Istilah kepuasan kerja merujuk pada sikap (reaksi emosional) seorang individu terhadap pekerjaannya. Davis \& Nestrom dalam Wahjono (2004) mendefinisikan kepuasan kerja sebagai keadaan emosional yang menyenangkan atau tidak menyenangkan dengan mana karyawan memandang pekerjaan mereka. Kepuasan kerja mencerminkan perasaan seseorang terhadap pekerjaannya. Ini nampak dalam sikap positif karyawan terhadap pekerjaan dan segala sesuatu yang dihadapi di lingkungan kerjanya.

Kepuasan kerja karyawan akan menghasilkan kinerja yang baik dan meningkat. Hal itu sangat berdampak positif bagi perusahaan karena memberikan manfaat-manfaat yang dapat membantu perusahaan mencapai tujuannya. Manfaat atau dampak yang dapat dirasakan oleh perusahaan atas kepuasan kerja karyawannya antara lain: mengurangi turn over karyawan, mengurangi biaya produksi, mengurangi resiko barang cacat sehingga terhindar dari complaint pelanggan, meningkatkan nilai dari penjualan, serta dapat meningkatkan kualitas perusahaan di mata para pelanggan dan calon pelanggan.

PT. Etowa Packaging Indonesia merupakan salah satu perusahaan manufaktur yang ada di kota Batam. Perusahaan ini memproduksi berbagai macam kemasan sesuai dengan kebutuhan pelanggan. Untuk tetap mengoperasikan bisnis ini, perusahan ini tidak bisa lepas dari bantuan para karyawan terutama karyawan bagian produksi. Setiap harinya ribuan kemasan diproduksi oleh bagian produksi dengan menggunakan mesinmesin yang telah ditentukan untuk memenuhi kebutuhan pelanggan. 
Septerina \& Rusda, pengaruh kompensasi terhadap kepuasan kerja karyawan....

Sudah telihat jelas bahwa karyawan bagian produksi merupakan salah satu bagian terpenting dalam mendukung aktivitas perusahaan. Kehadiran dan waktu yang mereka berikan harus terus dihargai. Untuk itu hak karyawan berupa kompensasi harus terus diperhatikan oleh pihak perusahaan. Kompensasi yang diberikan diharapkan dapat memberikan motivasi kerja sehingga produktivitas dapat terus meningkat dan dapat memberikan kepuasan tersendiri bagi para karyawan. berikut:

Tujuan dari penelitian ini adalah sebagai

1. Untuk mengetahui pengaruh kompensasi finansial terhadap kepuasan kerja karyawan pada bagian produksi di PT. Etowa Packaging Indonesia.

2. Untuk mengetahui pengaruh kompensasi non finansial terhadap kepuasan kerja karyawan pada bagian produksi di PT. Etowa Packaging Indonesia.

3. Untuk mengetahui pengaruh kompensasi finansial dan kompensasi non finansial secara bersama terhadap kepuasan kerja karyawan bagian produksi di PT. Etowa Packaging Indonesia.

\section{KAJIAN PUSTAKA \\ Kompensasi}

Menurut Desler dalam Yani (2012) kompensasi adalah semua bentuk penggajian atau ganjaran mengalir kepada pegawai dan timbul dari kepegawaiannya mereka. Menurut Handoko dalam Yani (2012) kompensasi adalah segala sesuatu yang diterima para karyawan sebagai balas jasa untuk kerja mereka.

Menurut Yani (2012) jenis-jenis kompensasi dapat dibedakan menjadi dua bentuk, yaitu:

1. Kompensasi dalam bentuk finansial

Kompensasi finansial dibagi menjadi dua bagian, yaitu kompensasi finansial yang dibayarkan secara langsung seperti gaji, upah, komisi dan bonus. Kompensasi finansial yang diberikan secara tidak langsung seperti tunjangan kesehatan, tunjangan pensiun, tunjangan hari raya, tunjangan perumahan, tunjangan pendidikan dan lain sebagainya.

2. Kompensasi dalam bentuk non finansial

Kompensasi non finansial dibagi menjadi dua macam, yaitu yang berhubungan dengan pekerjaan dan yang berhubungan dengan lingkungan kerja. Yang berhubungan dengan pekerjaan, misalnya kebijakan perusahaan yang sehat, pekerjaan yang sesuai (menarik, menantang), peluang untuk dipromosikan, mendapatkan jabatan sebagai simbol status. Sedangkan kompensasi non finansial yang berhubungan dengan lingkungan kerja seperti ditempatkan dilingkungan kerja yang kondusif, fasilitas kerja yang baik dan lain sebagainya.

Menurut Wahjono (2008) kompensasi adalah segala sesuatu yang diterima oleh karyawan sebagai imbalan atas sumbangan kepada perusahaan, termasuk di dalamnya adalah gaji, pemberian tunjagan, fasilitas-fasilitas yang dapat dinikmati karyawan baik yang berupa uang maupun yang bukan. Kompensasi merupakan salah satu fungsi operasional manajemen sumber daya manusia yang vital dan sangat mempengaruhi kemajuan perusahaan. Banyak perusahaan yang maju karena kebijakan kompensasinya baik dan sebaliknya. Dalam teori hierarchy of needs Maslow, kompensasi adalah faktor motivator sedangkan dalam teori Herzberg, kompensasi merupakan salah satu faktor pemeliharaan.

Secara individual, kompensasi adalah penting bagi karyawan karena:

1. Besarnya kompensasi mencerminkan ukuran nilai prestasi dan penghargaan perusahaan terhadap karyawan dibandingkan karyawan lainnya, keluarga, dan masyarakat.

2. Besarnya kompensasi merupakan ukuran status sosial, martabat, dan "harga" karyawan

\section{Kepuasan Kerja}

Menurut Handoko (2011) kepuasan kerja (job satisfaction) adalah keadaan emosional yang menyenangkan atau tidak menyenangkan dengan mana para karyawan memandang pekerjaan mereka. Kepuasan kerja mencerminkan perasaan seseorang terhadap pekerjaannya. Ini nampak dalam positif karyawan terhadap pekerjaan dan segala sesuatu yang dihadapi di lingkungan kerjanya.

Menurut Wahjono (2008) kepuasan kerja adalah hasil persepsi para karyawan tentang seberapa baik pekerjaan seseorang memberikan segala sesuatu yang dipandang sebagai suatu yang penting melalui hasil kerjanya.

Terdapat tiga penyebab utama kepuasan kerja, yaitu:

a. Faktor organisasional (seperti: gaji, peluang promosi, work it self, kebijakan dan kondisi pekerjaan).

b. Faktor kelompok (seperti: coworkers dan supervisor).

c. Faktor personal (seperti: kebutuhan, aspirasi, dan instrument benefits) 
Respon terhadap ketidakpuasan kerja karyawan bermacam-macam, mulai dari yang konstruktif (membangun) sampai pada yang bersifat merusak (destruktif). Respon ketidakpuasan karyawan yang pasif juga bisa berupa konstruktif yaitu loyalitas (kesetiaan), sedangkan yang destruktif berupa pengabaian tugas dan pembangkangan.

Karyawan yang kurang mendapatkan kepuasan kerja akan cenderung sering absen. Mereka sering tidak merencanakan untuk absen, tetapi bila ada alasan untuk absen, mereka lebih mudah menggunakan alasan-alasan tersebut.

Menurut Strauss dan Sayles dalam Handoko (2011), kepuasan kerja juga penting untuk aktualisasi diri. Karyawan yang tidak memperoleh kepuasan kerja tidak akan pernah mencapai kematangan psikologis, dan pada gilirannya akan menjadi frustasi. Karyawan seperti ini akan sering melamun, mempunyai semangat kerja rendah, cepat lelah dan bosan, emosinya tidak stabil, sering absen dan melakukan kesibukan yang tidak ada hubungannya dengan pekerjaan yang harus dilakukan. Sedangkan karyawan yang mendapatkan kepuasan kerja biasanya mempunyai catatan kehadiran dan perputaran yang lebih baik, kurang aktif dalam kegiatan serikat karyawan, dan (kadang-kadang) berprestasi kerja lebih baik daripada karyawan yang tidak memperoleh kepuasan kerja. Oleh karena itu, kepuasan kerja mempunyai arti penting baik bagi karyawan maupun perusahaan, terutama karena menciptakan keadaan positif di dalam lingkungan kerja perusahaan.

\section{Hipotesis}

1. H1 : Kompensasi finansial berpengaruh signifikan terhadap kepuasan kerja karyawan di bagian produksi.

2. H2 : Kompensasi non finansial berpengaruh signifikan terhadap kepuasan kerja karyawan di bagian produksi.

3. H3 : Kompensasi finansial dan kompensasi non finansial secara bersama berpengaruh terhadap kepuasan kerja karyawan di bagian produksi.

\section{METODE PENELITIAN}

Rancangan penelitian yang dilakukan oleh peneliti merupakan penelitian penjelasan atau explanatory research. Penelitian ini dilakukan di PT. Etowa Packaging Indonesia dengan menyebarkan kuesioner kepada sampel sebanyak
171 responden. Teknik penarikan sampel yang digunakan adalah purposive sampling, di mana sampel yang diambil hanya pada karyawan di bagian Produksi saja pada PT. Etowa Packaging Indonesia. Metode analisis data yang digunakan yaitu dengan statistik deskriptif dan analisis regresi berganda.

\section{HASIL DAN PEMBAHASAN}

Kuesioner yang disebarkan kepada responden telah melalui uji validitas menggunakan korelasi Product moment dan reliabilitas instrumen menggunakan Cronbach Alpha. Terdapat 15 item pertanyaan yang diajukan kepada responden telah memenuhi syarat valid dan reliabel. Hasil uji validitas instrumen dapat dilihat pada tabel sebagai berikut:

\begin{tabular}{|c|c|c|c|}
\hline $\begin{array}{c}\text { No Butir } \\
\text { Instrumen }\end{array}$ & $\begin{array}{c}\text { r tabel } \\
\boldsymbol{\alpha}=5 \%\end{array}$ & $\begin{array}{c}\text { Koefisien } \\
\text { Korelasi }\end{array}$ & Keterangan \\
\hline 1 & 0.148 & 0.539 & Valid \\
\hline 2 & 0.148 & 0.647 & Valid \\
\hline 3 & 0.148 & 0.710 & Valid \\
\hline 4 & 0.148 & 0.688 & Valid \\
\hline 5 & 0.148 & 0.675 & Valid \\
\hline 6 & 0.148 & 0.604 & Valid \\
\hline 7 & 0.148 & 0.642 & Valid \\
\hline 8 & 0.148 & 0.657 & Valid \\
\hline 9 & 0.148 & 0.683 & Valid \\
\hline 10 & 0.148 & 0.704 & Valid \\
\hline 11 & 0.148 & 0.657 & Valid \\
\hline 12 & 0.148 & 0.671 & Valid \\
\hline 13 & 0.148 & 0.608 & Valid \\
\hline 14 & 0.148 & 0.575 & Valid \\
\hline 15 & 0.148 & 0.586 & Valid \\
\hline
\end{tabular}

Sumber: data diolah, 2015

\section{Deskripsi Responden}

Rincian tentang deskripsi responden dari populasi karyawan di bagian produksi ditampilkan dalam tabel sebagai berikut:

Tabel 1. Deskripsi Responden

\begin{tabular}{|l|l|c|}
\hline Profil Responden & Klasifikasi & Jumlah \\
\hline $\begin{array}{l}\text { Kelompok Sub } \\
\text { Produksi }\end{array}$ & EPS & 40 \\
\hline & GP & 15 \\
\hline & VF & 116 \\
\hline Jenis Kelamin & Laki-Laki & 71 \\
\hline & Perempuan & 100 \\
\hline Usia & & 150 \\
\hline & $18-30$ tahun & 21 \\
\hline & $31-40$ tahun & 0 \\
\hline & $41-50$ tahun & 0 \\
\hline & $>51$ tahun & 164 \\
\hline Level of education & SLT A Sederajat & 4 \\
\hline & Diploma 3 & 3 \\
\hline & Sarjana 1 & 60 \\
\hline & & 48 \\
\hline Lama Bekerja & $<1$ tahun & 50 \\
\hline & $1-2$ tahun & 13 \\
\hline & $2-3$ tahun \\
\hline & $>3$ tahun & \\
\hline & & \\
\hline
\end{tabular}


Septerina \& Rusda, pengaruh kompensasi terhadap kepuasan kerja karyawan....

\section{Uji Asumsi Klasik}

\section{Uji Multikolinieritas}

Tabel 4

Uji Multikolinieritas

\begin{tabular}{|c|c|c|c|c|c|c|c|c|}
\hline \multicolumn{9}{|c|}{ Coefficients ${ }^{*}$} \\
\hline \multirow{2}{*}{\multicolumn{2}{|c|}{ Model }} & \multicolumn{2}{|c|}{$\begin{array}{c}\text { Unstandardized } \\
\text { Coefficients }\end{array}$} & \multirow{2}{*}{\begin{tabular}{|c|}
$\begin{array}{c}\text { Standardized } \\
\text { Coefficients }\end{array}$ \\
Beta \\
\end{tabular}} & \multirow[t]{2}{*}{$t$} & \multirow[t]{2}{*}{ Sig. } & \multicolumn{2}{|c|}{$\begin{array}{l}\text { Collinearity } \\
\text { Statistics }\end{array}$} \\
\hline & & $\mathrm{B}$ & Std. Error & & & & \begin{tabular}{|l|} 
Tolerance \\
\end{tabular} & VIF \\
\hline \multirow{3}{*}{1} & (Constant) & 6.914 & 1.328 & & 5.208 & .000 & & \\
\hline & $x_{1}$ & .236 & .116 & .230 & 2.041 & .043 & .297 & 3.372 \\
\hline & $x_{2}$ & .423 & .119 & .400 & 3.554 & .000 & .297 & 3.372 \\
\hline
\end{tabular}

Sumber: hasil pengolahan SPSS (2015)

Berdasarkan uji multikolinieritas melalui SPSS yang telah dilakukan di atas maka diketahui nilai VIFnya adalah $1.197<3.372$, dapat disimpulkan bahwa tidak terjadi multikolinieritas pada penelitian ini.

\section{Uji Autokorelasi}

\section{Tabel 5}

Uji Autokorelasi

\begin{tabular}{|l|c|r|r|r|r|}
\hline Model & $R$ & R Square & $\begin{array}{r}\text { Adjusted } \\
\text { R Square }\end{array}$ & $\begin{array}{c}\text { Std. Error of the } \\
\text { Estimate }\end{array}$ & $\begin{array}{c}\text { Durbin- } \\
\text { Watson }\end{array}$ \\
\hline 1 & $.606^{\mathrm{a}}$ & .368 & .360 & 2.13876 & 1.703 \\
\hline
\end{tabular}

Sumber: hasil pengolahan SPSS (2015)

Diketahui : $4-\mathrm{dw}=4-1.703=2.297$

4-dw $=2.297 \geq \mathbf{d}_{\mathbf{u}}=1.789$ maka Ho diterima, yang artinya bahwa tidak terdapat autokorelasi negatif pada penelitian ini.

\section{Uji Heteroskedastisitas}

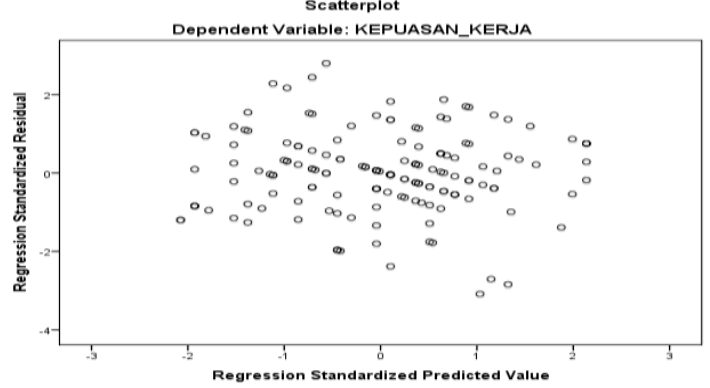

Grafik 1. Uji Heteroskedastisitas

Sumber : hasil pengolahan SPSS (2015)

Berdasarkan grafik di atas terlihat jelas bahwa titik-titik menyebar di atas dan di bawah angka 0 pada sumbu $\mathrm{Y}$, maka dapat disimpulkan bahwa tidak terjadi heteroskedastisitas.

\section{Uji Normalitas}

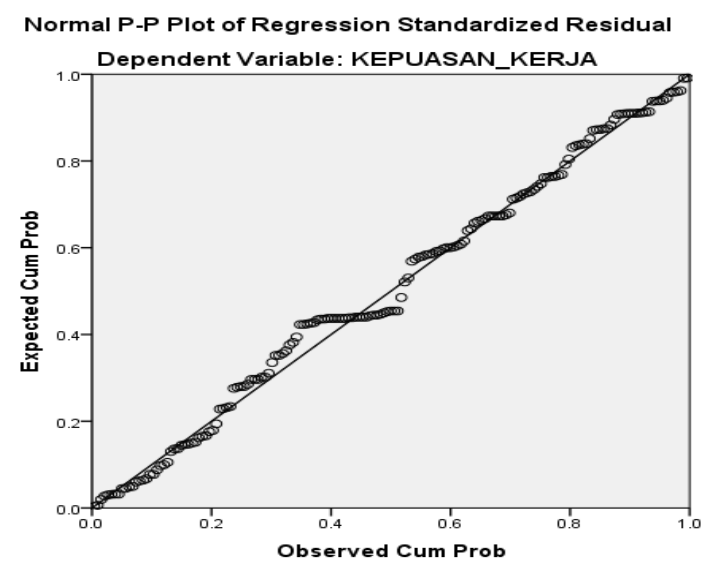

Grafik 2 Uji Normalitas

Sumber : hasil pengolahan SPSS (2015)

Dari grafik di atas terlihat bahwa titik titik menyebar di sekitar garis diagonal dan mengikuti arah garis diagonalnya. Dengan demikian model regresi ini memenuhi asumsi normalitas.

\section{Regresi Linier Berganda}

Tabel 6

Analisis Regresi Linier berganda

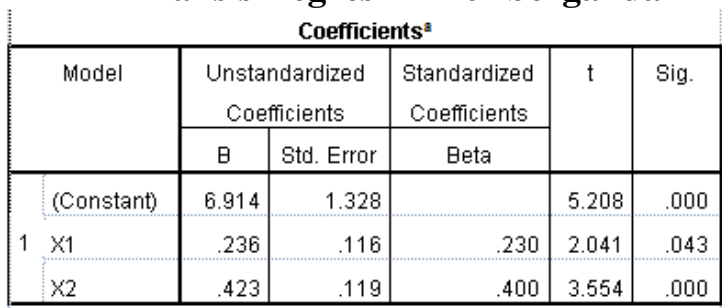

Sumber: hasil pengolahan SPSS (2015)

Berdasarkan hasil perhitungan di atas kolom kedua Unstandardized Coefficients bagian B dapat dimasukan ke dalam persamaan regresi linier berganda sebagai berikut:

$\mathrm{Y}=\mathrm{a}+\mathrm{b} \mathrm{X}_{1}+\mathrm{c} \mathrm{X}_{2}$

$\mathrm{Y}=6.914+0.236 \mathrm{X}_{1}+0.423 \mathrm{X}_{2}$

\section{Pengujian Hipotesis \\ 1. Uji t}

Tujuan pertama dalam penelitian ini adalah untuk mengetahui pengaruh secara parsial dari variabel kompensasi yang terdiri dari Kompensasi Finansial (X1) dan Kompensasi Non Finansial (X2) terhadap Kepuasan Kerja Karyawan (Y) pada bagian produksi di PT. Etowa Packaging Indonesia. 
Tabel 7

Uji t

\begin{tabular}{|l|r|c|r|r|r|}
\hline Model & \multicolumn{2}{|c|}{$\begin{array}{c}\text { Unstandardi } \\
\text { zed } \\
\text { Coefficients }\end{array}$} & $\begin{array}{c}\text { Standardi } \\
\text { zed } \\
\text { Coefficie } \\
\text { nts }\end{array}$ & $\mathrm{t}$ & $\begin{array}{r}\text { Si } \\
\mathrm{g} .\end{array}$ \\
\cline { 2 - 4 } & $\mathrm{B}$ & $\begin{array}{c}\text { Std. } \\
\text { Error }\end{array}$ & Beta & & \\
\cline { 1 - 3 } (Consta & 6.91 & 1.328 & & 5.20 & .00 \\
$\mathrm{nt})$ & 4 & & & 8 & 0 \\
$1 \mathrm{X} 1$ & .236 & .116 & .230 & 2.04 & .04 \\
1 & 3 \\
X2 & .423 & .119 & .400 & 3.55 & .00 \\
4 & 0 \\
\hline
\end{tabular}

Sumber: hasil pengolahan SPSS (2015)

Dari uraian tabel di atas maka diketahui bahwa nilai thitung $(\mathrm{X} 1)$ adalah 2.041 , dan nilai thitung (X2) adalah 3.554. Nilai dari setiap variabel X1 dan X2 menunjukan bahwa nilai tersebut $>$ ttabel 1.65397, maka dapat ditarik kesimpulan bahwa $\mathrm{Ha}$ diterima. Dengan demikian terdapat pengaruh yang signifikan secara parsial antara variabel kompensasi finansial terhadap variabel kepuasan kerja karyawan, dan variabel kompensasi non finansial terhadap variabel kepuasan kerja karyawan.

\section{Uji F}

Tujuan kedua dari penelitian ini yaitu untuk mengetahui pengaruh kompensasi finansial (X1) dan kompensasi non finansial (X2) secara bersama-sama terhadap kepuasan kerja karyawan (Y) pada bagian produksi di PT. Etowa Packaging Indonesia.

\section{Tabel 8 \\ Uji F}

ANOVA $^{\mathrm{a}}$

\begin{tabular}{|c|c|c|c|c|c|}
\hline Model & $\begin{array}{l}\text { Sum } \\
\text { of } \\
\text { Squar } \\
\text { es }\end{array}$ & $\mathrm{df}$ & $\begin{array}{c}\text { Mean } \\
\text { Squar } \\
\text { e }\end{array}$ & $\bar{F}$ & Sig. \\
\hline $\begin{aligned} & \text { Regress } \\
& \text { ion } \\
1 & \text { Residua } \\
1 & \\
& \text { Total }\end{aligned}$ & $\begin{array}{r}446.6 \\
75 \\
768.4 \\
83 \\
1215 . \\
158\end{array}$ & $\begin{array}{r}16 \\
8 \\
17 \\
0\end{array}$ & $\begin{array}{r}223.3 \\
37 \\
4.574\end{array}$ & $\begin{array}{r}48.8 \\
24\end{array}$ & $\begin{array}{r}.000 \\
\mathrm{~b}\end{array}$ \\
\hline
\end{tabular}

Sumber: hasil pengolahan SPSS (2015)

Dari tabel di atas nilai $\mathrm{F}_{\text {hitung }}$ adalah 48.824 $>$ dari $\mathrm{F}_{\text {tabel }} 3.05$, maka dapat disimpulkan bahwa Ha diterima yang artinya terdapat pengaruh yang signifikan antara kompensasi finansial (X1) dan kompensasi non finansial (X2) secara bersama terhadap kepuasan kerja karyawan (Y).

\section{SIMPULAN DAN SARAN Simpulan}

1. Variabel kompensasi finansial berpengaruh secara signifikan terhadap kepuasan kerja karyawan di bagian produksi, hal ini dibuktikan juga dengan uji deskriptif yang didapatkan dari penilaian responden. Pada variabel kompensasi finansial ini. setiap indikator gaji/upah, tunjangan lebur, tunjangan kesehatan, tunjangan hari raya, dan tunjangan pensiun berada pada daerah postif - sangat positif, hanya ada sedikit indikator yang memang harus disosialisasikan Kepada karyawan bagian produksi seperti perhitungan tunjangan lembur, perhitungan tunjangan hari raya, tunjangan pensiun bagi yang permanen, dan yang terakhir yaitu harus mensosialisasikan juga mengenai detail untuk tunjagan kesehatan. Sosialisasi ini dapat juga dilakukan pada saat hari pertama pelatihan karyawan baru.

2. Variabel kompensasi non finansial berpengaruh terhadap kepuasan kerja karyawan di bagian produksi. Ini juga bisa terlihat dari uji deskriptif yang telah penulis lakukan. Pada uji ini diketahui bahwa mean dari setiap indikator berada pada daerah positif - sangat positif. Untuk variabel ini bagian yang harus terus dikontrol yaitu indikator lingkungan dan fasilitas, karena lingkungan kerja dan fasilitas yang baik dapat memberikan kenyaman kerja karyawan.

3. Secara bersama-sama kompensasi finansial dan kompensasi non finansial berpengaruh terhadap kepuasan kerja karyawan di bagian produksi. Hal ini dibuktikan dengan uji F. Berdasarkan uji deskriptif yang telah dilakukan kepuasan kerja ini berada pada daerah positif - sangat positif.

\section{Saran}

Saran yang bisa diberikan dari penelitian ini sebagai berikut:

1. Pihak perusahaan memberikan sosialisasi pada saat hari pertama karyawan bekerja tidak hanya 
Septerina \& Rusda, pengaruh kompensasi terhadap kepuasan kerja karyawan....

mngenai ruang lingkup perusahaan tetapi juga memberikan sosialisasi mengenai besarnya upah, perhitungan lembur, tunjangan kesehatan, tunjangan hari raya dan tunjangan pensiun bagi karyawan permanen (jika ada).

2. Pihak HRD sebaiknya meminta calon pekerja membaca surat kontraknya sebelum menandatanganinya. Agar mereka mengetahui peraturan dan ketentuan perusahaan dengan baik sebelum memulai pekerjaan mereka.

3. Hasil penelitian ini dapat digunakan sebagai informasi dan saran bagi pihak manajemen dalam syarat dan ketentuan pemberian kompensasi kepada karyawan.

4. Memberikan informasi kepada pihak manajemen sebagai bahan pertimbangan untuk mengambil keputusan dalam perubahan prosedur atau praturan yang berkaitan dengan kompensasi

\section{DAFTAR PUSTAKA}

Agung Hidayanto, Djamhur Hamid, Moehammad Soe'oed Hakam (2014). Pengaruh Kompensasi Finansial dan Non Finansial Terhadapa Motivasu dan Kinerja Karyawan. Studi pada karyawan PT. AXA Financial Indonesia Cabang Malang.

Angga Putra Samudra, Kusdi Rahardjo, M. Djudi Mukzam (2014). Pengaruh Kompensasi Finansial Terhadap Kinerja. Studi pada Karyawan PT. Bank Jatim Cabang Malang.

Asghar Ali, Muhammad Naseem Akram (2012). Impact of Financial Rewards on Rmployee's Motivation and Satistfaction in Pharmaceutical Industry, Pakistan.

Bangun, Wilson. (2012). Manajemen Sumber Daya Manusia. Jakarta: Erlangga.

Danny Hendra Irawan, Djamhur Hamid, Muhammad Faisal Riza (2014). Pengaruh Kompensasi Finansial dan Kompensasi Non Finansial Terhadap Kinerja. Studi pada Agen AJB Bumiputera 1912 Kantor Cabang Blitar.

Fahrur Rozi (2014). Pengaruh Kompensasi Finansial dan Non Finansial Terhadap Kepuasan Kerja Karyawan. Studi Pada MBrother Group Lamongan.

Ghozali, Imam (2006). Aplikasi Analisis Multivariate Dengan Program SPSS. Semarang : Badan Penerbit Universitas Diponegoro.
Handoko, Hani (2011). Manajemen Personalia \& Sumber Daya Manusia (Edisi Kedua). Yogyakarta : BPFE-Yogyakarta.

Indriantoro, Nur \& Supomo, Bambang (2002). Metodologi Penelitian Bisnis (Edisi Pertama). Yogyakarta : BPFE-Yogyakarta.

Riva'i, Veithzal. (2004). Manajemen Sumber Daya Manusia untuk Perusahaan dan Teori ke Praktek. Jakarta: Raja Grafindo.

Sugiyono (2008). Metode Penelitian Bisnis (Pendekatan Kuantitatif, Kualitatif dan $R \& D)$ (Cetakan Kesebelas). Bandung : Alfabeta.

Umar, Husein (2009). Metode Penelitian Untuk Skripsi dan Tesis Binis (Edisi Kedua). Jakarta : Rajawali Pers.

Wahjono, Sentot Imam (2008). Manajemen Tata Kelola Organisasi Bisnis (Cetakan Pertama). Jakarta : PT INDEKS

Yani (2012). Manajemen Sumber Daya Manusia. Jakarta : Mitra Wacana Media. 